\title{
Dinamika Populasi Diaphorina citri Kuwayama (Homoptera: Psyllidae) dan Deteksi CVPD dengan Teknik PCR
}

\section{NYOMAN WIJAYA, WAYAN ADIARTAYASA, MADE SRITAMIN, DAN KETUT AYU YULIADHI}

\author{
PS. Agroekoteknologi Fakultas Pertanian Universitas Udayana
}

(diterima Juni 2010, disetujui Agustus 2010)

\begin{abstract}
The Population Dynamic of Diaphorina citri Kuwayama (Homoptera: Psyllidae) and Molecular Detection of CVDP With PCR. The research was conducted in the field of Taro village (600 $\mathrm{m}$ above the sea) Gianyar regency and Katung village (1200 m above the sea) Bangli regency and at the Laboratory of Biotechnology Faculty of Agricultural Udayana University in April to October 2009. The purpose of the research were to investigate population dynamic of Diaphorina citri Kuwayama and other insects that were assosiated with citrus cv. siam; and molecular detection of CVPD patogen in its vector, other phytophagous insects on citrus cv.siam and kemuning [Murraya paniculata (L.) Jack.] The result of this study showed that in six month period there was one peak of $D$. citri population which was associated with the flushing period of citrus at Taro as well Katung villages. The peak of $D$. citri population of Taro village was higher than that of Katung village. Two species of parasitoids and four spesies of predators were found in the field and may contribute in the suppression of D. citri population. The parasitoids identified were Tamarixia radiata Wat. and Diaphorencyrtus alligharensi Shaffe, whereas the predators were Curinus coeruleus Mulsant, Phiddipus sp., Menochilus sexmaculatus Fabricius and Oxyopes javanus Thorell. T. radiata has been proven to be an effective nymph parasitoid that could suppress the population development of $D$. citri in citrus orchads. The research revealed that kemuning could serve as a source of infection because it is also a host of CVPD disease as well as of $D$. citri. Toxoptera citricidus Kirkaldy and Maleuterpes dentipes Hell. were not proven to contain CVPD disease.
\end{abstract}

KEY WORDS: Population dynamic, Diaphorina citri, CVPD, PCR.

\section{PENDAHULUAN}

Produksi jeruk di Indonesia sejak tahun 1995 sampai 1998 mengalami penurunan yaitu pada tahun 1995 dari 1.004.631 ton turun menjadi 730.860 ton pada tahun 1996, 696.422 ton pada tahun 1997 dan 613.759 pada tahun
1998. Sampai saat ini produktivitas jeruk di Indonesia masih rendah yaitu berkisar 8,6 - 15 ton/ha/tahun (BPS 1995), sedangkan di daerah tropik lainnya produktivitas jeruk mencapai 20 ton/ha, bahkan di daerah produsen utama jeruk dunia di daerah subtropik dapat mencapai 40 ton/ha. Produktivitas yang rendah ini antara lain 
disebabkan oleh adanya serangan Diaphorina citri Kuwayama (Homoptera: Psyllidae). D. citri merupakan serangga hama utama pada tanaman jeruk, karena perannya sebagai vektor penyakit CVPD (Citrus Vein Phloem Degeneration) (Hoy \& Nguyen 1998). Patogen CVPD adalah bakteri Liberobacter yang dapat dideteksi dengan teknik Polymerase Chain Reaction (PCR) menggunakan primer $16 \mathrm{~S}$ rDNA (Bove et al. 1996).

Serangan penyakit CVPD paling parah pernah terjadi di SambasKalimantan Barat dan Tejakula-Bali pada tahun 1985 (Nurhadi \& Djatmiadi 2002). Serangan penyakit CVPD di Bali terus mengalami peningkatan yaitu 55.886 pohon terserang pada periode tahun 1997/1998 dan pada periode tahun 1998/1999 tanaman terserang sebanyak 90.326 pohon sehingga laju perkembangannya $61,63 \%$. Selanjutnya pada periode tahun 1999/2000 tanaman terserang meningkat menjadi 392.136 pohon. Dengan demikian berarti laju perkembangannya mencapai 334,13\% (Suwela et al. 2001).

Penelitian ini bertujuan untuk mengetahui dinamika populasi $D$. citri, serangga-serangga lainnya yang berasosiasi dengan tanaman jeruk, baik berupa predator, parasitoid dan hama lainnya serta mengetahui keberadaan patogen CVPD pada D. citri dan serangga lain yang berasosiasi pada tanaman jeruk dengan metode PCR.

\section{BAHAN DAN METODE}

\section{Dinamika Populasi D. citri}

Penelitian dilakukan selama enam bulan yaitu sejak akhir April sampai dengan Oktober 2009 pada pertanaman jeruk siam di dua desa dengan ketinggian dari permukaan laut yang berbeda yaitu 600 meter di Desa Taro, Kecamatan Tegallalang Kabupaten Gianyar dan 1200 meter di Desa Katung, Kecamatan Kintamani Kabupaten Bangli. Desa Taro mempunyai suhu rata-rata $25,2{ }^{0} \mathrm{C}$ dan Desa Katung mempunyai suhu rata-rata 20,7 ${ }^{0} \mathrm{C}$. Pengamatan populasi D. citri dilakukan dengan menghitung langsung imago pada setiap sampel tanaman, kemudian ditangkap dengan menggunakan aspirator. Pengamatan dilakukan mulai pukul 08:00 - 17:00 Wita.

\section{Musuh Alami}

Keberadaan dan peran musuh alami dievaluasi melalui kegiatan inventarisasi musuh alami, tingkat parasitisasi parasitoid dan kelimpahan predator. Inventarisasi dan tingkat parasitisme parasitoid dilakukan dengan metode Nurhadi dan Whittle (1989). Dinamika predator yaitu Curinus coeruleus Mulsant, Menochilus sexmaculatus Fabricus, Phiddipus sp. dan Oxyopes javanus Thorell dilakukan dengan menghitung langsung pada setiap tanaman sampel dan dideskripsi melalui ciri morfologi berdasarkan Shepard et al. (1988). 


\section{Serangga-serangga Lainnya}

Pemantauan lalat buah (Bactrocera spp.) dilakukan dengan menggunakan metode yang dilakukan oleh Ditlin (1994) yaitu pemasangan perangkap metil eugenol (Petrogenol 800L) yang bersifat atraktan. Untuk luas kebun satu hektar dipasang secara diagonal 10 buah perangkap.

\section{Perkembangan Penyakit CVPD}

Pengamatan ini bertujuan untuk mengetahui perkembangan penyakit CVPD. Pengamatan dilakukan terhadap 100 tanaman jeruk yang diambil secara acak, kemudian diberi tanda dengan tali rafia. Pada awal dan akhir percobaan dilakukan pencatatan terhadap populasi tanaman yang terserang penyakit CVPD.

\section{Deteksi Penyakit CVPD pada $D$. citri, Tanaman Jeruk, Tanaman Kemuning dan Serangga lain yang Berasosiasi dengan Tanaman jeruk}

Penelitian dilakukan di laboratorium Bioteknologi, Jurusan Hama dan Penyakit Tumbuhan, Fakultas Pertanian Universitas Udayana. Imago dan nimfa instar 4 D. citri yang digunakan berasal dari tanaman jeruk yang bergejala CVPD di lapangan dan dari hasil pemeliharaan pada tanaman jeruk terserang CVPD di laboratorium, sedangkan telur D. citri berasal dari tanaman jeruk terserang CVPD di laboratorium. Imago Toxoptera citricidus dan Maleuterpes dentipes yang digunakan merupakan hasil penangkapan pada tanaman jeruk ber- gejala CVPD di lapangan dan telah dipelihara pada tanaman jeruk siam terserang CVPD di laboratorium selama tiga hari. Deteksi juga dilakukan pada daun, ujung ranting jeruk, bibit jeruk terserang CVPD di lapangan dan daun kemuning yang diambil dari hasil penularan di laboratorium. Jumlah masing-masing bahan yang digunakan untuk deteksi adalah sebagai berikut: imago D. citri sebanyak 5 ekor, nimfa D. citri sebanyak 10 ekor, telur D. citri sebanyak 20 butir, imago T. citricidus sebanyak 5 ekor, imago $M$. dentipes sebanyak 3 ekor, potongan tulang daun jeruk sebanyak 3 helai dan potongan tulang daun kemuning sebanyak 5 helai. Deteksi molekuler dengan teknik PCR melalui tahapan :a) isolasi total DNA, b) amplifikasi DNA dan c) visualisasi hasil PCR.

\section{HASIL DAN PEMBAHASAN}

\section{Kelimpahan D. citri}

Hasil pengamatan selama enam bulan yaitu sejak akhir April sampai dengan akhir Oktober 2009 menunjukkan bahwa terjadi satu kali puncak populasi D.citri yaitu bulan September, baik di Desa Taro maupun desa Katung. Puncak-puncak populasi $D$. citri berkaitan dengan masa pertunasan jeruk siam. Pertumbuhan tunas muda merangsang imago betina $D$. citri untuk meletakan telurnya, setelah $2-3$ hari dari peletakan telur. Pertunasan merupakaan periode kritis, sehingga perlu mendapat perhatian yang serius. 
Puncak populasi D. citri di kedua tempat penelitian mempunyai pola yang sama, tetapi berbeda waktu dan tinggi puncak tersebut. Puncak populasi di Desa Taro terjadi pada minggu II September 2009 (9,9 ekor per pohon), sedangkan di Desa Katung minggu III bulan September 2009 (8 ekor per phon) (Gambar 1). Siklus hidup $D$. citri berlangsung antara $16-$ 18 hari pada kondisi panas, sedangkan pada kondisi dingin sampai 45 hari (Ditlin 1994). Rataan suhu di Desa Taro $25,2{ }^{\circ} \mathrm{C}$ dengan kisaran $23,1^{\circ} \mathrm{C}-$ $27,3{ }^{\circ} \mathrm{C}$, sedangkan di Desa Katung $20,7{ }^{\circ} \mathrm{C}$ dengan kisaran $18,8-22,4{ }^{\circ} \mathrm{C}$. Menurut Chen (1998), suhu optimal perkembangan $D$. citri berkisar $22-$ $29^{\circ} \mathrm{C}$, sedangkan kisaran suhu $19,5-$ $31,5{ }^{\circ} \mathrm{C}$ mempengaruhi peningkatan serangga dewasa berkopulasi (Nurhadi et al. 1986). Hal ini menunjukkan perkembangan dan keaktifan serangga dewasa berkopulasi di dusun Taro berada dalam kondisi optimal.

Populasi D. citri menurun setelah masa pertunasan dan terendah pada saat panen yaitu bulan Juli, hal ini disebabkan karena tidak tersedianya tunas-tunas muda sebagai tempat peletakan telur dan pakan bagi nimfa $D$. citri. Keadaan yang serupa ditemukan di Taiwan yaitu setelah tanaman disemprot insektisida, populasi $D$. citri mencapai nihil, tetapi muncul kembali setelah masa pertunasan tanpa penyemprotan (Chien \& Chu 1996). Oleh karena itu, pola pertunasan dapat digunakan sebagai indikator fluktuasi populasi $D$. citri, sehingga saat pengendalian dapat dilakukan secara tepat.

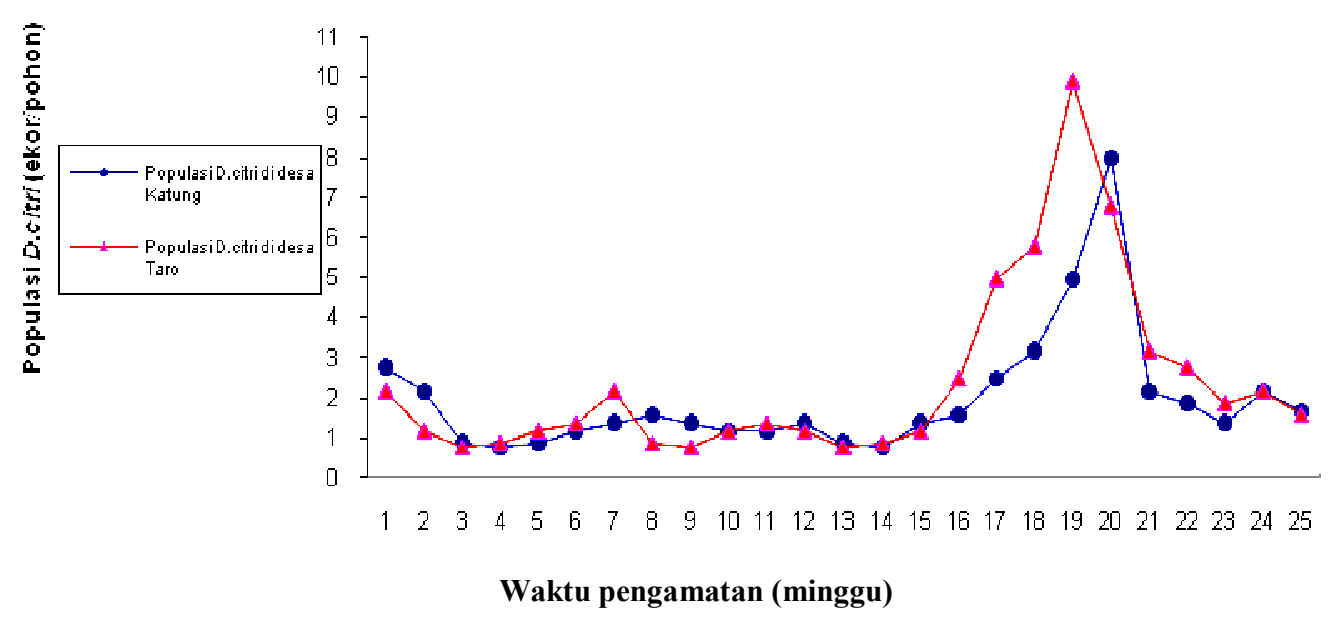

Gambar 1. Dinamika pupulasi D. citri pada pertanaman jeruk siam di Desa Kantung 
D. citri selalu dijumpai pada setiap pengamatan dengan kisaran populasi 0,12 - 9,9 ekor per pohon. Tampaknya populasi tersebut tidak menimbulkan kerugian langsung pada pertumbuhan tanaman, karena tidak menyebabkan kematian tunas atau mengeringnya daun. Walaupun demikian, kerugian tidak langsung disebabkan oleh $D$. citri adalah sebagai vektor penyakit CVPD yang merupakan penyakit serius dan selalu mengancam pertumbuhan dan produksi jeruk. Hal tersebut terbukti dari pertambahan luas serangan CVPD berkisar antara 20 - 29\% selama penelitian. Pada awal pengamatan di Desa Taro tanaman terserang CVPD sebanyak 51\% meningkat menjadi $80 \%$ pada akhir pengamatan, sedangkan di Desa Katung berawal dari 39\% menjadi 59\%. Fenomena ini diperkuat dari hasil deteksi molekuler yang menunjukkan D. citri mengandung patogen CVPD, sehingga berpotensi sebagai vektor penyakit CVPD.

\section{Musuh Alami D. citri}

Musuh alami yang ditemukan pada kedua lokasi penelitian adalah 2 jenis parasitoid dan 4 jenis predator. Kedua jenis parasitoid tersebut merupakan parasitoid nimfa yaitu Tamarixia radiata Wat. (Hymenoptera: Eulophidae) dan Diaphorencyrtus alligharensis Shaffe (Hymenoptera: Encyrtidae), sedangkan predator yang ditemukan dua jenis dari famili Coccinelidae yaitu Menochilus sexmaculatus Fabricius dan Curinus coeruleus Mulsant serta 2 jenis laba-laba yaitu Phidippus sp. Dari famili Salticidae dan Oxyopes javanus Thorel dari famili Oxyopidae.

Tingkat parasitisasi parasitoid nimfa $T$. radiata di dusun Taro lebih tinggi dibandingkan di Desa Katung masingmasing dengan kisaran bertu-rut-turut $29,55 \%$ - $64,79 \%$ dan $21,05 \%$ $57,64 \%$. Hasil penelitian ini menunjukkan bahwa $T$. radiata lebih berperan dalam mengendalikan populasi D. citri dipertanaman jeruk dibandingkan $D$. alligharensis, karena tingkat parasitisasi $D$. alligharensis berkisar antara $0-3,38 \%$ di Desa Taro dan 2,4\% - 15,78\% di Desa Katung. Hasil yang sama juga telah dilaporkan oleh Nurhadi dan Whittle (1989), yang menemukan 2 jenis parasitoid nimfa yaitu $T$. radiata dan D. alligharensis pada pertanaman jeruk di daerah Malang, Probolinggo, Pemekasan, Magetan dan Tulungagung, Jawa Timur, dengan tingkat parasitisasi oleh T. radiata $61,62-89,84 \%$ dan $D$. alligharensis 7,14-66,84\%.

Curinus coeruleus merupakan predator D. citri yang selalu dijumpai di pertanaman jeruk, baik di Desa Taro maupun Katung. Rataan populasinya berkisar 0,2 - 2 ekor per pohon di Desa Taro dan 0,08 - 1,92 ekor per pohon di Desa Katung. Rendahnya populasi predator ini diduga karena $D$. citri tidak merupakan mangsa utama $C$. coeruleus. Uji pemangsaan C. coeruleus terhadap D. citri pada tanaman kemuning (Murraya paniculata) di 
laboratorium menunjukkan bahwa predator ini mampu memangsa berbagai stadium $D$. citri (Istianto \& Setyobudi, 1996), bahkan C. coeruleus lebih banyak memangsa $D$. citri dibandingkan kutu loncat lamtoro $(H$. cubana) yang merupakan mangsa utamanya (Supartha \& Susila 2001).

Populasi M. sexmaculatus pada kedua lokasi penelitian sangat rendah dengan kisaran $0,2-1,2$ ekor per pohon di Desa Taro dan $0-1,88$ ekor per pohon di Desa Katung $M$. sexmaculatus merupakan predator yang bersifat polifag yang memangsa berbagai jenis kutu daun seperti Aphis maidis pada tanaman jagung dan bermacam kutu pada tanaman kopi (Kalshoven 1981). Predator ini juga memangsa D. citri (Sudarno 1987). Hasil pengujian laboratorium menunjukkan seekor $M$. sexmaculatus mampu memangsa $4-8$ ekor selama 12 jam (Isharsono 2000). Ditemukan dua jenis laba-laba yaitu Phiddipus sp. Dan Oxyopes javanus di kedua lokasi penelitian. Populasi tersebut berkisar $0,12-1,2$ ekor per pohon

\section{Serangga-serangga Lainnya}

Serangga lain yang ditemukan berasosiasi pada tanaman jeruk adalah kutu daun jeruk, Toxoptera citricidus Kirk. (Homoptera: Aphididae); lalat buah, Bactrocera spp. (Diptera: Tephritidae); kumbang belalai jeruk, Maleuterpes dentipes Hell. (Coleoptera:Curculionidae); kepik hitam, Rhyncocoris poseidon Kirk. (Hemip- tera: Pentatomidae), dan keong racun Achatina fulica Fer. (Molusca).

T. citricidus merupakan pesaing D. citri karena mempunyai relung yang sama pada pucuk dan daun muda tanaman jeruk. Populasinya selalu lebih tinggi dibandingkan $D$. citri pada setiap pengamatan. Populasi T. citricidus berkisar antara 0,48 - 112 ekor per pohon dan $D$. citri berkisar antara 0,12 - 9,9 ekor per pohon di Desa Taro. Sedangkan di Desa Katung populasi $T$. citricidus berkisar antara 0,12 - 38,08 ekor per pohon dan D. citri berkisar antara $0,12-7,92$ ekor per pohon.

Lalat buah, (Bactrocera spp.) merupakan hama yang selalu dijumpai pada setiap pengamatan, baik di Desa Taro maupun di Desa Katung. Hasil penangkapan dengan atraktan metil eugenol yang dilakukan secara teratur, menunjukkan populasi tertinggi terjadi menjelang panen pada bulan Juli 2009, dan Juni 2009 berturut-turut 152 ekor, dan 174 ekor per perangkap per hari di Desa Taro, sedangkan di Desa Katung adalah 87 ekor dan 111 ekor.

Populasi M. dentipes di Desa Katung berkisar 0,12 - 3,38 ekor per pohon, sedangkan di Desa Taro $0-1,6$ ekor per pohon. Pada umumnya populasi rendah terjadi pada musim hujan, kemudian meningkat dan mencapai puncaknya akhir bulan April 2009 sebesar 3,38 ekor per pohon di Desa Katung dan September 2009 di Desa Taro yaitu 1,16 ekor perpohon. 
$R$. poseidon adalah hama yang menyerang buah jeruk di pertanaman. Kisaran populasinya antara $0,5-9,8$ ekor per pohon di Desa Taro dan 0,52 - 10,48 ekor per rumpun di dusun Katung.

4. Deteksi Penyakit CVPD pada $D$. citri, Tanaman Jeruk, Tanaman Kemuning dan Serangga lain yang Berasosiasi pada Tanaman jeruk

\subsection{Deteksi Patogen CVPD pada} Serangga $D$. citri

Hasil visualisasi elektroforesis pada gel agarose 1\% menunjukkan bahwa PCR berhasil mengamplifikasi patogen CVPD dari imago dan nimfa yang hidup pada tanaman jeruk bergejala CVPD di lapangan maupun hasil pemeliharaan pada tanaman jeruk terinfeksi CVPD di laboratorium (Gambar 2). Hal ini menjelaskan bahwa imago dan nimfa $D$. citri dapat berperan sebagai vektor penyakit CVPD. Hasil penelitian Wijaya (2003), membuktikan bahwa imago $D$. citri dalam jumlah 1, 3 dan 5 ekor mampu menularkan penyakit CVPD. Marlina (1998) juga menyatakan bahwa 5 ekor nimfa D. citri mampu menularkan penyakit CVPD pada bibit tanaman jeruk Siam dan Rough Lemon (Marlina 2000). Hasil analisis PCR terhadap telur yang diletakkan imago D. citri yang hidup pada tanaman jeruk terinfeksi CVPD di laboratorium, menunjukkan hasil yang negatif karena tidak terbentuk pita-pita DNA dari patogen CVPD. Hal ini menunjukkan bahwa patogen CVPD tidak terbawa melalui telur ke generasi berikutnya.

\subsection{Deteksi Patogen CVPD pada $T$. citricidus dan $M$. dentipes}

Hasil penelitian menunjukkan bahwa dari $T$. citricidus dan $M$. dentipes tidak diperoleh pita DNA produk PCR (Gambar 2). Hal ini menunjukkan bahwa $T$. citricidus dan M. dentipes tidak dapat mengakuisisi patogen CVPD sehingga keduanya tidak potensial menjadi vektor penyakit CVPD.

\section{Deteksi Patogen CVPD dari Tanaman Jeruk dan Kemuning}

Hasil visualisasi elektroforesis pada gel agarose 1\% menunjukkan bahwa dengan teknik PCR berhasil diamplifikasi patogen CVPD dari daun, ranting, bibit jeruk dan tanaman kemuning bergejala CVPD, baik di lapangan maupun hasil penularan di laboratorium (Gambar 2). Hal ini menunjukkkan bahwa daun, ranting, bibit jeruk dan tanaman kemuning mengandung patogen CVPD.

Deteksi awal pada bibit jeruk sangat penting sebelum bibit tersebut ditanam maupun diedarkan. Keberadaan patogen CVPD pada bibit tidak cukup dengan melihat gejala saja karena bakteri mungkin sudah ada, tetapi belum menampakkan gejala, apalagi gejala serangan CVPD mirip dengan gejala klorosis yang terjadi karena kekurangan unsur $\mathrm{Zn}, \mathrm{Fe}, \mathrm{Mn}$ atau N (Tirtawidjaja \& Suharsojo 1990). 


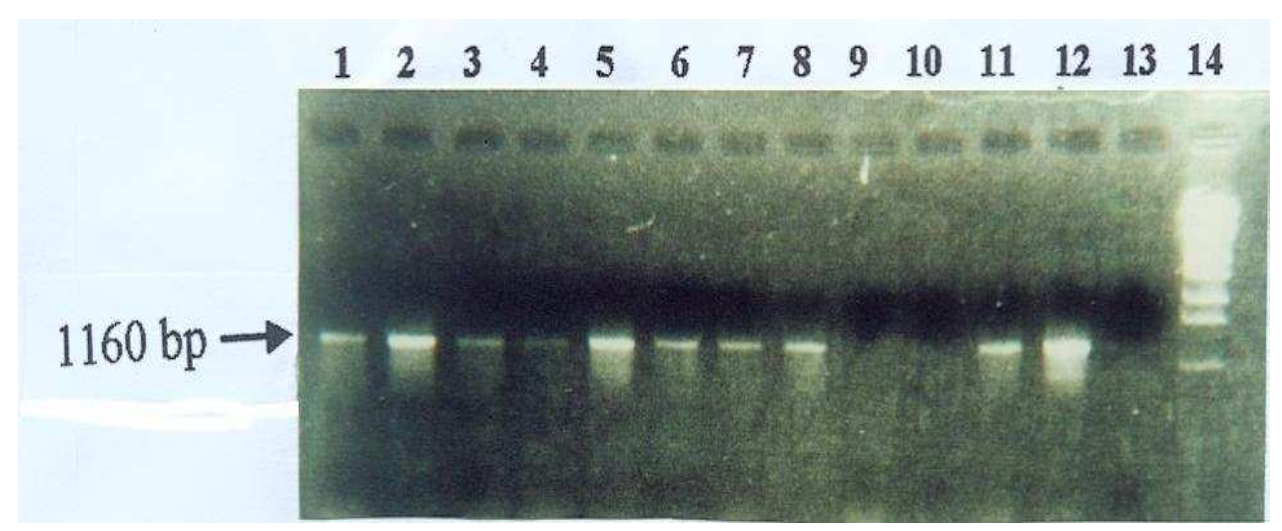

Gambar 2. Hasil Amplifikasi Bakteri Patogen CVPD pada D. citri, T. citricidus, $M$. dentipes, Daun Jeruk dan Daun Kemuning dengan Teknik PCR. Lajur 1) Daun jeruk bergejala CVPD di lapangan, 2) Daun jeruk bergejala CVPD di laboratorium, 3) Ujung ranting jeruk bergejala CVPD di lapangan, 4) Ujung ranting jeruk bergejala CVPD di laboratorium, 5) Imago D. citri pada tanaman jeruk bergejala CVPD di lapangan, 6) Imago D. citri pada tanaman jeruk terinfeksi CVPD di laboratorium, 7) Nimfa $D$. citri pada tanaman jeruk bergejala CVPD di lapangan, 8) Nimfa $D$. citri pada tanaman jeruk terinfeksi CVPD di laboratorium, 9) Imago T. citricidus pada tanaman jeruk bergejala CVPD di lapangan, 10) Imago $M$. dentipes pada tanaman jeruk bergejala CVPD di lapangan 11) Daun bibit jeruk bergejala CVPD, 12) Daun kemuning bergejala CVPD, 13) Telur D. citri pada tanaman jeruk terinfeksi CVPD di laboratorium, dan 14) DNA marker.

Penyebaran penyakit CVPD dalam jarak jauh terjadi karena terbawa bibit sakit, oleh karena itu harus dilakukan deteksi yang akurat terhadap bibit yang ditanam ataupun yang diedarkan. Gambar 2. Hasil Amplifikasi Bakteri Patogen CVPD pada D. citri, T. citricidus, M. dentipes, Daun Jeruk dan Daun Kemuning dengan Teknik PCR. Lajur 1) Daun jeruk bergejala CVPD di lapangan, 2) Daun jeruk bergejala CVPD di laboratorium, 3) Ujung ranting jeruk bergejala CVPD di lapangan, 4) Ujung ranting jeruk bergejala CVPD di laboratorium, 5)
Imago D. citri pada tanaman jeruk bergejala CVPD di lapangan, 6) Imago D. citri pada tanaman jeruk terinfeksi CVPD di laboratorium, 7) Nimfa $D$. citri pada tanaman jeruk bergejala CVPD di lapangan, 8) Nimfa $D$. citri pada tanaman jeruk terinfeksi CVPD di laboratorium, 9) Imago T. citricidus pada tanaman jeruk bergejala CVPD di lapangan, 10) Imago $M$. dentipes pada tanaman jeruk bergejala CVPD di lapangan 11) Daun bibit jeruk bergejala CVPD, 12) Daun kemuning bergejala CVPD, 13) Telur D. citri 
pada tanaman jeruk terinfeksi CVPD di laboratorium, 14) DNA marker.

\section{KESIMPULAN DAN SARAN}

\section{Kesimpulan}

Dinamika populasi Diaphorina citri dipengaruhi oleh fase pertumbuhan tanaman jeruk, suhu lingkungan dan musuh alaminya. Populasi D. citri tertinggi terjadi pada masa pertunasan tanaman. Ditemukan dua jenis parasitoid nimfa yang berperan menekan perkembangan D. citri. Tamarixia radiata merupakan parasitoid nimfa yang berperan menekan perkembangan populasi D. citri pada pertanaman jeruk siam dengan tingkat parasitisasinya berkisar antara 21,05 64,79\%. Serangga D. citri pada pertanaman jeruk siam tidak berstatus sebagai hama, tetapi lebih berperan sebagai vektor penyakit CVPD. Serangga $D$. citri merupakan satusatunya vektor penyakit CVPD diantara serangga-serangga yang ditemukan berasosiasi dengan tanaman jeruk.

\section{Saran}

Serangga $D$. citri sebagaimana telah dipaparkan sebelumnya tidak sebagai hama pada pertanaman jeruk siam, tetapi berperan sebagai vektor penyakit CVPD. Oleh karena itu apabila ditemukan serangga vektor walaupun dalam populasi yang rendah perlu segera dikendalikan.

\section{DAFTAR PUSTAKA}

Biro Pusat Statistik. 1995. Survei Pertanian Produksi Tanaman Sayuran dan Buah-buahan. Jakarta : BPS

Bove JM, Jogoueiix, Garnier M. 1996. PCR Detection of the two andidates Liberobacter species associared with greening diseases of citrus. Moleculer and Cellular Probes 10:43-50.

Chen CN. 1998. Ecology of the insect vector of citrus systemic diseases and their control in Taiwan. Citrus Greening Control Project in Okinawa, Japan. Extension Bulletin $459: 1-5$.

Chien CC, Chu YI. 1996. Biological control of citrus psyllid, Diaphorina citri in Taiwan. In: Biological Pest Control in Systems of Integrated Pest Management; Taiwan, Octo-ber 1993. Taipe-Taiwan: Food and Fertilizer Technology Center for the Asian and Pacibc Region, Taipei, Taiwan. p. 93-105.

[Ditlin] Direktur Bina Perlindungan Tanaman. 1994. Pengelolaan Organisme Pengganggu Tumbuhan secara Terpadu pada Tanaman Jeruk. Jakarta: Direktorat Jenderal Tanaman Pangan

Hoy MA, Nguyen R. 1998. Citrus psylla. Here in Florida. http:// extlab7.entnem ufl.edu/PestAlert. [diakses Juni 2010]

Isharsono. 2000. Identifikasi dan inventarisasi musuh alami Diaphorina citri Kuv. (Homoptera : Psyllidae) vektor penyakit 
CVPD pada tanaman jeruk [skripsi]. Denpasar : Universitas Udayana, Fakultas Pertanian.

Istianto M, Setyobudi L. 1996. Potensi individu Curinus coeruleus Mulsant famili Coccinellidae sebagai predator Diaphorina citri Kuwayama. Hortikultura 6(3): 269274.

Kalshoven LGE. 1981. Pests of Crops in Indonesia. Laan PA van der, penerjemah. Jakarta : PT Ichtiar Baru-van Hoeve. Terjemahan dari : De Plagen van de Cultuurgewassen in Indonesie.

Koesmaryono Y. 1985. Biologi kutudaun gandum Rhopalosiphum padi Linnaeus (Homoptera : Aphididae) di dua habitat dengan iklim yang berbeda [tesis]. Bogor: Institut Pertanian Bogor, Fakultas Pascasarjana, Jurusan Agroklimatologi.

Marlina. 2000. Penularan penyakit CVPD melalui Diaphorina citri Kuw stadia imago dan nimfa pada jeruk rough lemon dan siem. Agristal. hlm 204-207.

Nurhadi, Styobudi L, Handoko. 1986. Biologi kutu psyllid Diaphorina citri Kuwayama (Homoptera : Psyllidae). Penel Hort 19:369643

Nurhadi, Whittle AM. 1989. Parasites of CVPD vector (Diaphorina citri Kuw.) in East Java with reference to the prospect of biological control. Solok : Penel Hort 3(3): 65-72

Nurhadi, Djatmiadi D. 2002. Manajemen hama dan penyakit tanaman jeruk : hasil penelitian dan implementasi. Di dalam:
Semiloka Nasional Pengembangan Jeruk dan Pameran Buah Jeruk Unggulan. Bogor, 10-11 Juli 2002.

Shepard BM, Barrion AT, Litsinger JA. 1988. Helpful Insects, Spiders and Pathogens. Philippines : International Rice Research Institute.

Sudarno S. 1987. Jagung : Pengendalian Serangga Hama. Yogyakarta: Kanisius

Supartha IW, Susila IW. 2001. Uji Pemangsaan Curinus coeruleus Mulsant (Coleoptera: Coccinellidae) terhadap Diaphorina citri Kuw. (Homoptera: Psyllidae) dan Heteropsylla cubana Crawford (Homoptera: Psyllidae). Agritrop 20(1):5-9.

Suwela N, Darmika W, Sadi K. 2001. Evaluasi dan Pemetaan Daerah Serangan Penyakit CVPD pada Tanaman Jeruk di Bali [laporan]. Denpasar: Balai Proteksi Tanaman Pangan dan Hortikultura VII

Tirtawidjaja S, Suharsojo R. 1990. Penyakit CVPD merupakan bahaya laten bagi tanaman jeruk di Indonesia [editorial]. Perlindungan Tanaman Menunjang Terwujudnya Pertanian Tangguh dan Kelestarian Lingkungan. PT. Agricon. Hlm. 299 - 310.

Wijaya IN. 2003. Diaphorina citri Kuwayama (Homoptera : Psyllidae) : Bioekologi dan peranannya sebagai vektor Penyakit CVPD pada tanaman jeruk [disertasi]. Bogor: Institut Pertanian Bogor : Program Pascasarjana 